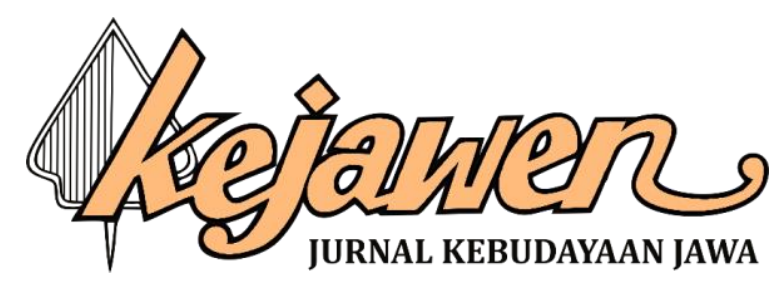

\title{
NILAI-NILAI ETIKA HUBUNGAN MANUSIA DENGAN DIRI PRIBADI DALAM SERAT PUSTAKA WASIAT
}

\author{
Azis Heru Iswanto \\ Pendidikan Bahasa Jawa, Fakultas Bahasa dan Seni, Universitas Negeri Yogyakarta \\ azisheru.2020@student.uny.ac.id
}

\begin{abstract}
Abstrak
Penelitian ini betujuan menguraikan nilai-nilai etika hubungan manusia dengan diri pribadi yang terkandung dalam naskah Serat Pustaka Wasiat karya Raden Nata Atmaja. Metode yang digunakan adalah metode penelitian filologi modern serta metode penelitian deskriptif. Sumber data penelitian ini adalah naskah dan teks Serat Pustaka Wasiat yang tersimpan di Museum Sonobudoyo Yogyakarta dengan nomor kodeks PBC 197. Teknik pengumpulan data menggunakan langkah penelitian filologi yaitu (1) inventarisasi naskah, (2) deskripsi naskah, (3) alih tulis teks, (4) suntingan teks, (5) terjemahan teks, serta (6) analisis isi. Analisis data menggunakan teknik analisis deskriptif. Hasil penelitian ini menjelaskan tujuh jenis nilai etika hubungan manusia dengan diri pribadi. Ketujuh nilai tersebut adalah ahklak ngati-ati dalam berbicara, watak nrima akan cobaan dan keberuntungan dari Allah, rumangsan bahwa setiap manusia memiliki aib pribadi, sikap waspada dalam berperilaku dan sifat sombong, mencegah hawa nafsu dengan cara laku prihatin, bersikap adil dalam memikirkan keduniawian dan kerohanian, dan sabar dalam menerima cobaan.
\end{abstract}

Kata kunci: etika, Pustaka Wasiat, manusia, diri pribadi

\section{ETHICAL VALUES OF HUMANRELATIONSHIP WITH ONESELF IN SERAT PUSTAKA WASIAT}

\begin{abstract}
This study aims to describe the ethical values of human relations with oneself contained in the manuscript of Serat Pustaka Wasiat by Raden Nata Atmaja. The method used is modern philological research and descriptive research methods. The data sources of this research are the manuscripts and texts of Serat Pustaka Wasiat which are stored in the Sonobudoyo Museum in Yogyakarta with codex number PBC 197. The data collection technique uses philological research steps, namely (1) manuscript inventory, (2) manuscript descriptions, (3) text transfer, (4) text editing, (5) text translation, and (6) content analysis. The data analysis is using descriptive analysis techniques. The results of this study explain seven types of ethical values of human relationships with oneself. The seven values are the morality of ngati-ati in speaking, nrima character in trials and luck from Allah, rumangsan that every human being has personal disgrace, alertness in behavior and arrogance, preventing lust by being concerned, being fair in thinking about worldliness and spirituality, and patience in accepting trials.
\end{abstract}

Keywords: etichal, Pustaka Wasiat, human, oneself

\section{PENDAHULUAN}

Peninggalan orang Jawa adalah salah satu hasil cipta, rasa, dan karsa orang Jawa zaman dahulu. Peninggalan tersebut dapat berupa tulisan dan non tulisan. Peninggalan yang berwujud non tulis contohnya seperti bangunan, makanan dan tari. Sedangkan yang berupa tulisan adalah pesan moral pujangga Jawa yang tertulis dalam sebuah naskah atau serat. Naskah peninggalan pujangga Jawa ditulis menggunakan aksara Jawa dengan wujud prosa maupun puisi Jawa. Naskahnaskah kuna tersebut tersimpan di berbagai tempat penyimpanan, seperti di Museum Sonobudoyo Yogyakarta, Museum Radya Pustaka Surakarta, Perpustakaan Reksa Pustaka Mangkunegaran dan 
masih banyak lagi bahkan ada yang tersimpan di luar negeri. Naskah yang tersimpan terdiri dari beribu-ribu naskah jumlahnya yang keadaannya benar-benar harus dijaga dan dilestarikan.

Naskah-naskah Jawa biasanya memuat pesan moral yang sangat berguna untuk hidup manusia. Pesan tersebut bermacam-macam, yaitu pesan dalam hal agama atau berhubungan dengan Tuhan, bab hidup manusia dalam bermasyarakat, ada juga dalam bab budaya. Pesan dalam naskah sangat berguna dan bermanfaat dalam menjalani hidup jika isinya dapat dimengerti oleh manusia jaman modern ini. Kegunaan pesan moral utamanya nilai-nilai etika dalam naskah yaitu sebagai sumber ilmu. Sumber ilmu dalam bertingkah laku manusia dalam menjalani hidup seharihari. Nilai etika zaman dahulu yang terdapat didalam naskah perlu dikaji dengan cara penelitian filologi dan isinya dapat diterapkan sebagai dasar untuk bertingkah laku manusia dalam bermasyarakat.

Salah satu naskah yang perlu diteliti adalah naskah Serat Pustaka Wasiat. Berdasarkan hasil inventarisasi naskah, naskah Serat Pustaka Wasiat hanya ditemukan di satu tempat yaitu Museum Sonobudoyo Yogyakarta. Naskah Serat Pustaka Wasiat (yang selanjutnya disebut SPW) disimpan di Museum Sonobudoyo dengan kode PBC 197. Naskah SPW adalah salah satu naskah Jawa yang ditulis dengan aksara Jawa dan menggunakan bahasa Jawa baru. Sedangkan teks ini digubah dalam bentuk tembang macapat/puisi Jawa. Naskah $S P W$ termasuk jenis naskah piwulang.

Naskah $S P W$ perlu diteliti berdasarkan keadaan dan isinya yang penting. Isi naskah ini perlu dibahas karena memuat berbagai ilmu. Keadaan naskah dan isi naskah dijelaskan sebagai berikut: 1) keadaan naskah $S P W$ masih baik. Jilidannya masih kencang. Tulisannya masih jelas dan masih bisa terbaca, walaupun ada beberapa bagian yang sulit dibaca. Oleh karena itu naskah $S P W$ perlu diteliti agar dapat dibahas isinya sebeum naskah ini mengalami kerusakan; b) apabila dilihat dari isinya, teks $S P W$ ini memiliki keunikan/kekhasan karena memuat ajaran filsafat. Filsafat yang dijelaskan dalam teks $S P W$ adalah filsafat manusia hidup di dunia mulai dai kandungan sampai meninggal yang akan menerima hasil dari perbuatannya pada saat hidup di dunia; tidak hanya filsafat, teks $S P W$ juga menjelaskan tentang asal mula manusia. Pada teks $S P W$ dijelaskan bahwa manusia yang perbuatannya tidak baik terlahir dari jagad peteng dan manusia yang memiliki sifat dan perilaku yang baik terlahir dari jagad padhang; selain itu, teks $S P W$ juga menjelaskan tentang pesan moral khususnya nilai etika manusia terhadap dirinya sendiri.

Penjelasan di atas hanya sebagian isi dari teks $S P W$. Tetapi itu sudah cukup menjelaskan bahwa naskah $S P W$ perlu diteliti karena mengandung berbagai ilmu pengetahuan yang penting. Dalam penelitian ini dipilih penjelasan nilai-nilai etika hubungan manusia dengan diri pribadi karena isi dari naskah ini lebih dominan membicarakan tentang nilai etika terhadap diri sendiri.

Nilai-nilai etika hubungan manusia dengan diri pribadi adalah etika yang membicarakan tingkah laku dan perbuatan manusia dalam hubungannya dengan dirinya sendiri, atau perbuatan manusia selaku pribadi (Hadiatmaja, 2011:11). Berhubungan dengan tingkah laku manusia kepada diri pribadinya sendiri tersebut ada nilai-nilai yang menjadi ukurannya. Lebih lanjut, Hadiatmaja (2011:55) menjelaskan bahwa manusia memiliki nilai kebaikan yaitu mawas dhiri, budi luhur, tepa slira, mrawira, rumangsan, dan ngerti ing sетu. Mawas dhiri dalam konteks ini adalah introspeksi diri; budi luhur adalah sifat baik manusia dalam menerima dengan rasa syukur; tepa slira maksudnya kesadaran diri bahwa ia tidak akan melakukan sesuatu yang andai kata ia diperlakukan semacam itu; mrawira maksudnya manusia yang murah hati dan menjaga harga dirinya; rumangsan adalah sikap perasa bahwa ia sebagai manusia sebagai mahkluk Tuhan yang selalu diawasi setiap perbuatannya; ngerti ing semu artinya kemampuan untuk dapat membaca isyarat baik melalui simbol-simbol (pasemon). Menurut Endraswara (2003:98-102) menjelaskan bahwa etika yang berhubungan dengan diri pribadi orang Jawa ada 3, yaitu (1) akhlak ngati-ati, (2) ora ngaya atau nrima, dan (3) pasrah sumarah.

Penelitian yang digunakan untuk meneliti naskah $S P W$ yaitu penelitian filologi. Filologi yaitu ilmu yang objek kajiannya berupa naskah dan teks. Menurut Pudjiastuti (2018:32) filologi yaitu ilmu yang mempelajari hasil karya jaman dahulu yang berwujud tulisan tangan, kajiannya 
lebih fokus pada teks atau yang terkandung dalam naskah, karya ini memuat nilai-nilai yang masih relevan pada kehidupan saat ini.

Ekowati (2017:25) menjelaskan bahwa langkah penelitian filologi yaitu (1) menentukan teks, (2) inventarisasi naskah atau manuskrip, (3) deskripsi naskah, (4) perbandingan naskah dan teks, (5) suntingan teks, (6) terjemahan, dan (7) analisis teks. Menurut Fathurahman (2016:87), langkah perbandingan naskah dan teks hanya dilakukan apabila jumlah naskah lebih dari satu, dan langkah ini tidak digunakan untuk naskah tunggal. Berdasarkan hasil inventarisasi naskah, naskah $S P W$ hanya ditemukan satu eksemplar saja. Oleh karena itu langkah penelitian filologi yang digunakan dalam penelitian ini adalah sebagai berikut: (1) inventarisasi naskah, (2) deskripsi naskah, (3) alih tulis teks, (4) suntingan teks, (5) terjemahan teks, dan (6) analisis isi.

\section{METODE}

Jenis penelitian yang digunkan dalam penelitian ini adalah penelitian filologi modern dan penelitian deskriptif. Sedangkan sumber data yang digunkan adalah naskah dan teks dengan judul Serat Pustaka Wasiat. Serat Pustaka Wasiat adalah salah satu teks yang ditulis dengan aksara Jawa dengan wujud tembang macapat yang merupakan koleksi Museum Sonobudoyo Yogyakarta dengan nomer kode PB C. 197. Teks Serat Pustaka Wasiat terbagi menjadi 14 pupuh, dari 14 pupuh yang dijadikan sumber data hanya 3 pupuh, yaitu dhandhanggula, kinanthi, dan sinom.

Teknik pengumpulan data pada penelitian ini menggunakan langkah penelitian filologi, yaitu (1) inventarisasi naskah dilakukan denan cara pengamatan langsung dan studi katalog; (2) deskripsi naskah dengan menjelaskan keadaan naskah secara nyata melalui kartu data dan dijelaskan secara naratif; (3) transliterasi teks dengan metode transliterasi standar; (4) suntingan teks dengan membenarkan kesalahan-kesalahan tulisan dalam naskah, sedangkan kata-kata yang dianggap salah dan tidak ditemukan maknanya dalam kamus akan disunting dengan membuat aparat kritik; (5) parafrase dengan cara mengubah wujud teks dari tembang menjadi prosa; dan (6) terjemahan teks dengan mengganti bahasa teks dari bahasa Jawa menjadi bahasa Indonesia. Teknik analisis data pada penelitian ini menggunakan analisis deskriptif. Tujuan menggunakan analisis deskriptif adalah untuk menjelaskan yang berwujud ujaran atau gambaran dari isi teks Serat Pustaka Wasiat. Cara ini menggunakan cara penafsiran dengan memberikan deskripsi. Langkah analisis data pada penelitian ini ada 4, yaitu (1) reduksi data, (2) klasifikasi data, (3) display data, dan (4) penafsiran (Kaelan, 2005:69-70).

\section{HASIL DAN PEMBAHASAN}

Hasil dan pembahasan yang ditulis dalam artikel ini lebih fokus terhadap nilai-nilai etika hubungan manusia dengan diri pribadi. Sedangkan hasil penelitian filologi terhadap teks Serat Pustaka Wasiat hanya ditulis secara singkat. Hasil tersebut diuraikan di bawah ini.

Tabel 1. Deskripsi Naskah dan Teks $S P \boldsymbol{W}$

\begin{tabular}{|c|c|c|}
\hline No. & Keterangan & Naskah Serat Pustaka Wasiat \\
\hline 1 & Judul bendel naskah & Serat Kempalan Warna-warni \\
\hline 2 & Tempat penyimpanan & Museum Sonobudoyo Yogyakarta \\
\hline 3 & Nomor kodeks & PB C.197 \\
\hline 4 & Judul teks yang diteliti & Serat Pustaka Wasiat \\
\hline 5 & $\begin{array}{l}\text { Judul } \\
\text { a. Tertulis dimana } \\
\text { b. Berdasakan keterangan dalam } \\
\text { teks atau katalog } \\
\text { c. Keterangan penulisan judul } \\
\text { naskah }\end{array}$ & $\begin{array}{l}\text { a. Judul tertulis pada halaman judul teks } \\
\text { dan dalam teks. } \\
\text { b. Berdasarkan keterangan dalam teks } \\
\text { dan dari katalog. } \\
\text { c. Judul ditulis oleh penulis pada halaman } \\
\text { judul teks dan bait awal teks } S P W \text {. }\end{array}$ \\
\hline
\end{tabular}




\begin{tabular}{|c|l|l|}
\hline No. & \multicolumn{1}{|c|}{ Keterangan } & \multicolumn{1}{|c|}{ Naskah Serat Pustaka Wasiat } \\
\hline 6 & Nama penulis & Raden Nata Atmaja \\
\hline 7 & $\begin{array}{l}\text { Penutup } \\
\text { a. Waktu Penulisan }\end{array}$ & $\begin{array}{l}\text { 4 Jumadilakir, Bé 1824 ( 3 Novèmbêr } \\
1894)\end{array}$ \\
\hline 8 & Keadaan naskah & $\begin{array}{l}\text { Naskah masih bagus dan tulisannya masih } \\
\text { dapat terbaca jelas. }\end{array}$ \\
\hline
\end{tabular}

Naskah $S P W$ merupakan salah satu naskah koleksi Museum Sonobudoyo Yogyakarta. Dari hasil inventarisasi naskah di beberapa tempat, naskah SPW hanya ditemukan di Museum Sonobudoyo Yogyakarta dengan nomor kodeks PBC 197. Keadaan naskah SPW masih bagus dan terawat. Naskah ini merupakan jenis naskah piwulang yang ditulis dengan menggunakan aksara Jawa. Bahasa yang digunakan dalam teks $S P W$ yaitu bahasa Jawa baru. Teks $S P W$ ditulis dengan bentuk gubahan tembang macapat atau puisi Jawa dengan jumlah pupuh sebanyak 14 pupuh yang keseluruhan baitnya berjumlah 372 bait. Keempat belas pupuh tersebut yaitu Dhandhanggula, Kinanthi, Sinom, Asmarandana, Kinanthi, Dhandhanggula, Sinom, Pangkur, Mijil, Maskumambang, Dhandhanggula, Kinanthi, Dhandhanggula, dan Sinom.

Naskah SPW merupakan naskah carik atau tulis tangan yang ditulis pada kertas HVS ukuran A5 dengan tinta berwarna hitam tebal. Wujud aksara teks $S P W$ adalah ngetumbar yang ditulis dengan posisi miring ke kanan. Jumlah halaman dari teks $S P W$ adalah 86 halaman yang mana terdapat 15 baris di setiap halamannya. Naskah SPW ditulis pada 4 Jumadilakir, Bé 1824 atau dalam kalender masehi pada 3 Novèmbêr 1894 (Behrend, 1990:507). Menurut yang tertulis dalam teksnya, naskah $S P W$ ini ditulis oleh Raden Nata Atmaja. Nama tersebut tertulis dalam baris ketiga bait pertama pupuh Dhandhanggula. Bunyi dari baris tersebut seperti pada kutipan di bawah ini.

Pamresing tyas sinawung memanis, yun manedhak Pustaka Wasiat, ing Radyan Natatmajane, kinon nganggya prasunu, kang dereng wrin rahsyeng kinteki, samya amersudyaa, away tyas balilu, lukitaning kang pustaka, bangsa rahsa supadya ngrunyep tyas peni, away keh nrang druaka.

Terjemahan:

Mengerahkan segala kekuatan melalui tembang dhandhanggula, saya menyalin Pustaka Wasiat yang ditulis oleh Raden Nata Atmaja untuk anak-anak yang belum mengerti isi surat ini. Maka belajarlah, jangan memiliki hati bodoh. Isi dari pustaka ini supaya merasuk dalam hati yang baik dan jangan melakukan perbuatan dosa.

Berdasarkan kutipan di atas bahwa teks $S P W$ sepertinya masih ada babon naskahnya yang belum diketahui tempat penyimpanannya. Terlihat jelas dalam baris kedua bait pertama pupuh Dhandhanggula terdapat kata manedhak yang dalam bahasa Indonesianya berarti menyalin. Dapat diambil kesimpulan bahwa teks $S P W$ ini adalah salinan dari babon naskahnya yang belum diketahui.

\section{Nilai-Nilai Etika Hubungan Manusia dengan Diri Pribadi}

Berdasarkan nilai-nilai etika hubungan manusia dengan diri pribadi menurut Hadiatmaja dan Endraswara, data yang ditemukan adalah akhlak ngati-ati, nrima, dan rumangsan. Di sisi lain terdapat temuan yang ditemukan peneliti yaitu nilai-nilai etika hubungan manusia dengan diri pribadi selain pendapat Hadiatmaja dan Endraswara. Nilai-nilai hubungan manusia dengan diri pribadi lainnya yaitu waspada, mencegah hawa nafsu, adil, dan sabar. 


\section{Akhlak Ngati-ati}

Akhlak ngati-ati yang terdapat dalam dalam teks $S P W$ adalah berhati-hati dalam berbicara. Kutipan data penjelasan akhlak ngati-ati dalam teks $S P W$ dijelaskan di bawah ini.

.... tegese bisa ing sastra/ nganggya ukara yen angling// (pupuh 2 bait ke 19)

Terjemahan:

.... Maksud dari mampu berbahasa sastra yaitu perlu memerhatikan kata yang akan digunakan berbicara.

nora benyunyak-benyunyuk/ kudu ganêp angastiti/ têgêsé kadyå wanitå/ luwês sasolah ngêrsêpi/ manis kêdaling wacånå/ adoh mring pênggawé sirik// (pupuh 2 bait ke 20)

Terjemahan:

(Saat berbicara) tidak bersikap seperti orang tanpa tahu tata krama, selalu berhati-hati dalam perkataan. Maksud dari seperti wanita adalah halus dalam tindakan dan indah saat dipandang. Manis dalam bertutur kata serta jauh dari perbuatan buruk.

Dari dua kutipan teks SPW diatas dijelaskan bahwamanusia harus berhati-hati dalam berbicara. Manusia berbicara harus menggunakan tata krama yang baik, memperhatikan suasana dan siapa yang menjadi lawan bicara, dan tidak terburu-buru dalam berbicara. Sesuai dengan pendapat Endraswara (2003:98) bahwa berbicara harus diatur, dipikir terlebih dahulu dan berbicara menggunakan aturan, tidak asal berbicara. Dari keterangan tersebut sudah jelas bahwa manusia sebelum berbicara harus dipikirkan terlebih dahulu, jangan sampai asal berbicara. Hal ini bertujuan agar tidak menyakiti hati lawan tutur kita pada saat kita berbicara.

\section{Nrima}

Nrima yang dijelaskan dalam teks $S P W$ adalah menerima apa adanya yang diberikan Tuhan. Kutipan data penjelasan nrima dalam teks $S P W$ dijelaskan di bawah ini.

...kumêndêlå ing Ywang Sukmå/ narimåå yen bejå durung tumitis/ têgsêna ingkang karyå// (Pupuh 1 bait ke 2)

Terjemahan:

...Berserah dirilah kepada Yang Maha Kuasa. Terimalah jika keberuntungan belum berpihak dengan tetap rajin bekerja.

dèn narimå pintanên ing batin/ aywå kongsi batal niyatirå/ ywå susah sinung lêlakon / laku kang nora jujur/ jêr jinajal atêping ati/ déning Ywang Måhå Mulyå/ yèn nyåtå pinujul/ kari nampani nugråhål bêjå iku tan kênå kikiréng jalmi/ yèn adoh ingkang karyå// (Pupuh 1 bait ke 15)

Terjemahan:

Terimalah dengan tulus hati jangan sampai batal niyatmu. Jangan bersedih dengan cobaan dan jangan sampai bertindak yang tidak jujur pada saat diuji ketulusan hati oleh Yhang Maha Mulya. Jika dapat melewati cobaan akan mendapatkan anugerah. Keberuntungan itu tidak akan pergi jika manusia itu tidak berhenti untuk berusaha. 
Dari dua bait kutipan teks $S P W$ di atas menjelaskan bahwa manusia hidup di dunia ini harus menerima apa saja yang diberikan Tuhan. Tidak hanya menerima yang berwujud keberuntungan akan tetapi juga menerima cobaan yang diberikan Tuhan dengan ikhlas. Dalam kehidupan masyarakat Jawa saat ini sering terdengar "nrima ing pandum", artinya adalah menerima apa yang telah menjadi takdir manusia tersebut (Hadiatmaja, 2011:56). Kata nrima mudah sekali untuk diucapkan, tetapi susah untuk menjalankannya. Manusia berikap nrima tersebut harus berlandaskan rasa ikhlas atau legawa menerima apa saja. Maka dari itu, manusia harus memepunyai watak nrima pada kehidupannya. Tidak hanya nrima saja, tetapi juga dibarengi dengan usaha dengan tekun supaya manusia bisa menjadi umat yang senantiasa bersyukur.

\section{Rumangsan}

Rumangsan adalah perilaku yang mengerti atau peka terhadap orang lain yang dimaksud dari rumangsan disini adalah manusia merasa bahwa setiap perilakunya ada yang mengawasi dan ada yang mencatat amal perbuatannya, tidak lain adalah Tuhan.

tutupên ingkang barukut/ kang bêcik gyan tanêrtibi/ åjå sirå rêmên mêdhar/ angudhar barang piningit/ tanpå asil tuwas sayah/ awêwah dipungêdhongi// (Pupuh 2 bait ke 4)

Terjemahan:

Jangan sesekali diumbar (aib orang lain) supaya kebaikan terus mengalir. Jangan menjadi seseorang yang senang membuka apa yang orang lain simpan rapat-rapat. Tidak berguna dan melelahkan diri sendiri. Bungkus rahasia itu dengan sebaik mungkin.

Berdasarkan kutipan teks SPW diatas dijelaskan bahwa manusia tidak diperbolehkan untuk membuka dan mengumbar aib orang lain. Manusia harus mengerti bahwa semua perilakunya di dunia ini ada diawasi oleh Tuhan. Tidak hanya itu, semua manusia yang ada di dunia ini memiliki cobaan, keberuntungan, dan sifat lupa. Manusia harus ngrumangsani bahwa diri pribadinya juga memiliki aib. Pepatah Jawa mengatakan manusia haru ngilo githok, harus ingat dengan kesalahan dan aibnya sendiri (Santosa, 2013:117). Keterangan tersebut menunjukan bahwa manusia harus ngrumangsani kesalahan dan tidak boleh membuka aib orang lain.

\section{Sikap Waspada}

Manusia ditakdirkan oleh Tuhan untu hidup di dunia ini supaya memiliki kewaspadaan diri. Waspada dari godaan, perilaku dan nafsu-nafsu yang bisa menghalangi manusia berperilaku pada jalan yang benar (Hadiatmaja, 2011:27). Sikap waspada yang dijelaskan dalam teks $S P W$ dibagi menjadi dua, yaitu waspada pada perilaku dan waspada pada sifat tidak baik. Lebih jelasnya dijelaskan di bawah ini.

\section{Waspada perilaku tidak baik}

marmå sirå ingkang ngati-atil tindak tanduk tatanên ing nålål nalikå lumêksananél wali-wali ingayun/ wêwulangé pårå binangkit/ tan ånå ingkang salah/ bênêr tur saèstu/ wênèh jalmå tan rinåså/ yèn kasusu sêngguh piyangkuh andadi/ bêging tyas wus sujånål/ (pupuh 1 bait ke 6)

Terjemahan:

Maka kamu berhati-hati, tingkah laku harus ditata didalam hati pada saat melakukannya. Berulang kali didepan, pesan dari para orang pintar tidak ada yang salah, semua benar, selain orang yang tidak merasa. Jika terburu-buru (untuk) sombong, susah dalam hati sudah merasa orang pintar. 
lamun lali dadyå luput/ luput sabarang kaptining/ sasêdyannyå nora tåmpå/ kélangan lamun tan éling/ kêlon kaluluning sétan/ tunajêning ing ngaurip// (pupuh 2 bait ke 11)

Terjemahan:

Ketika sudah lupa (tanda adanya Widi), maka akan menjadi kesalahan. Lagi tidak dapat memahami. Kehilangan arah saat lupa maka dia sedang tertidur dalam buaian setan. Tiada kehormatan dalam hidup.

Pada kutipan pupuh 1 bait ke 6 diatas dijelaskan bahwa manusia harus berhati-hati dalam berperilaku. Sebelum bertindak manusia harus ditata terlebih dahulu dalam hati. Hudiarini (2017:6) menjelaskan bahwa manusia yang menggunakan pikirannya pada saat akan bertindak sebagai sarana kontrol diri pribadi manusia dalam bertindak. Tujuannya supaya tidak membuat kecewa orang lain dan selamat dalam menjalankan semua pekerjaannya. Selain itu, pada pupuh 2 bait ke-11 dijelaskan bahwa manusia harus waspada pada perilaku lupa. Perilaku tersebut bisa menyebabkan tindakan yang salah, tindkan yang semaunya sendiri. Karena orang yang lupa akan mudah tergoda oleh setan pada pikirannya. Didalam Al Quran telah dijelaskan dalam surat AlMujadalah ayat 19 yang artinya "Setan telah menguasai mereka, lalu menjadikan mereka lupa mengingat Allah".

Waspada pada sifat yang tidak baik

malah pêdhotên kang wuwus/ sagung rapêtnyå kang manis/ lawan kang lagyå ingucap/ ywå kêbanjur mangrasani/ nanging åjå sirå mênggak/ bok mênåwå dadi ati// (pupuh 2 bait ke 2)

Terjemahan:

Justru putuskan kegiatan itu dan berusahalah menutupinya serapat mungkin. Apabila sudah terlanjur dibicarakan tetap jangan ikut menjelek-jelekkan. Siapa tau menyakitkan hati.

Dari keterangan di atas dijelaskan bahwa manusia harus menjauhi watak yang suka menjelek-jelekan atau membicarakan kejelekan orang lain. Watak tersebut bisa menyebabkan perselisihan terhadap tetangga sekitar kita. Endraswara (2003: 31) menjelaskan bahwa orang yang suka membicarakan kejelekan orang lain akan menganggap diri pribadinya yang paling benar, akan teteap orang lain yang ia bicarakan dianggap salah. Maka dari itu, watak yang seperti itu harus disingkiri. Jika orang ada orang yang mengetahui ada orang lain yang membicarakan kejelekan tetangganya maka harus diingatkan supaya tidak menyakiti hati orang lain. Watak tersebut juga bisa memecah belah kerukunan antar tetangga.

...ywa dumèh sampun ngèlmi/ sêngguhé alêngut-lêngut/ mamak barang mangêpak/ sok énakå ingkang galih/ nunjang palang ngèlmuné pinasang pasang// (pupuh 3 bait ke 8)

Terjemahan:

...jangan mentang-mentang sudah berilmu dirinya tidak mengenakkan, berbuat seenaknya sendiri tanpa aturan, menerjang ilmunya ditata-tata.

Dari keterangan di atas dijelaskan bahwa manusia yang sudah berilmu atau sudah pandai harus menjauhi watak sombong. Orang yang memiliki watak sombong karena sudah merasa pandai setelah itu bertindak semaunya sendiri tanpa tau aturan. Manusia harus ingat bahwa yang memiliki ilmu yang lebih sempurna itu hanyalah Allah. Hal itu sudah dijelaskan dalam Al Quran surat Yusuf ayat 76 yang artinya "dan tiap-tiap orang yang berpengetahuan itu ada lagi Yang 
Maha Mengetahui". Dari ayat tersebut manusia tidak boleh memiliki watak sombong, karena masih ada yang memiliki ilmu yang lebih sempurna. Maka dari itu manusia harus waspada pada sifat angkara, contohnya watak sombong.

\section{Mencegah Hawa Nafsu}

Nilai etika selanjutnya adalah mencegah hawa nafsu. Mencegah hawa nafsu merupakan perilaku prihatin, manusia yang senang laku prihatin akan mencapai hidup yang tentram. Pada teks $S P W$ sudah dijelaskan mengenai bab laku prihatin khususnya mencegah hawa nafsu.

Pupuh 1 bait ke 5

...jaganên jêjêging karså/ byati darmå napsu kang pinoting jisim/ pamurunging tyas arjål/

Terjemahan:

...jagalah tegaknya keinginan untuk menempuh kewajiban napsu didalam jiwa. Napsu yang menjadikan batalnya menuju hati yang bersih.

Pupuh 1 bait ke 19

dandanirå ingkang nêbadani/ nêmbadani laku kang raharjål jêr tapanirèng jisimél manyêgah dhahar nginum/ tapaning roh pan ora guling / tapèng tyas èstu sabar/ sabar barang kayun / mung sawiji ingkang mêdal/ sing tapèng tyas barang karså nêngêr jati/ mêsthi glis linampahan//

Terjemahan:

Perbaikilah perbuatanmu yang lebih baik. Dengan cara mencegah hawa napsu dalam badan. Mencegah makan minum dan tidur. Mencegah napsu hati dengan bersabda, dengan semua itu pasti akan tercapai semuanya.

\section{Pupuh 3 bait ke 11}

...têladan nguni-uni/ ingkang samyå tuwuh luhur/tan pisah sangking tåpå/ kang awas kang gawé urip/ yèn wus pasah sinêmbah samèng manungsåll

Terjemahan:

...Contoh yang sudah-sudah yang menjadi luhur tidak jauh dari perbuatan mencegah hawa nafsu, yang awas dalam hidup. Jika sudah fasih akan dicari oleh semua manusia.

Pupuh 3 bait ke 13

...lamun lêkas darbé kapti/ têmên-têmên norå ginggang/ rinéwang luwé lan $\operatorname{arip} / \ldots$

Terjemahan:

...jika memulai suatu keinginan, rajin tidak renggang dengan dibantu lapar dan rasa kantuk...

Dari keempat kutipan di atas bisa diambil kesimpulan bahwa manusia harus bisa mencegah hawa nafsunya. Dari keterangan di atas dijelaskan bahwa laku prihatin dijalani dengan cara mencegah hawa nafsu yang ada pada badan manusia, yaitu mengurangi makan dan tidur. Tujuannya supaya bisa tercapai yang dicita-citaka dan mencapai kehidupan yang tentram. Sudah 
dijelaskan contohnya dalam pupuh 3 bait ke 11 bahwa manusi zaman dulu yang memiliki derajat yang luhur senang dengan laku prihatin. Watak manusia yang suka mengurangi tidur memiliki sifat yang budi luhur, sedangkan watak manusia yang suka mengurangi makan mendapatkan kekuatan lahir batin (Musman, 2017: 29). Dari keterangan tersebut sudah jelas bahwa manusia hidup di dunia harus mau menjalankan laku prihatin supaya tentram hidupnya.

\section{Adil}

Kata adil dalam KBBI artinya sama berat, tidak berat sebelah, dan tidak memihak (https://kbbi.web.id/adil). Manusia yang memiliki watak dan perilaku adil terhadap diri pribadinya dan orang lain adalah manusia yang menggunakan akal dan pikirannya dengan baik. Perilaku adil juga dijelaskan dalam teks $S P W$. Contoh dari perilaku adil yang dijelaskan dalam teks $S P W$ diuraikan di bawah ini.

\section{Pupuh 1 bait ke 11}

.... rumangsannyå si ardå dupi / pinukul adil samar / marmå dipunémut / mèngêti tingkahé jalmå/ myang sêbarang kang gumêrmêt kang kumêlip / kapyå dadyå wêwulang//

Terjemahan:

.... Menurutnya si murka bersikap tidak adil, maka harus diingat semua tingkah polah manusia yang hanya mementingkan keindahan duniawi seperti menjadi pelajaran.

Pada kutipan pupuh 1 bait ke 11 dijelaskan bahwa manusia harus berperilaku adil. Adil yang dimaksud di pupuh 1 bait ke 11 ini adalah adil untuk senang suatu hal yang bersifat duniawi dan hal yang bersifat rohani. Perilaku adil adalah perilaku yang akan membawa kebaikan bagi kehidupan manusia. Magnis-Suseno (1998: 216) menjelaskan bahwa siapa saja umat manusia yang berperilaku benar, maka akan merasa selamat dan mendapatkan ketentraman hati dalam hidupnya. Perilaku benar yang dimaksud adalah perilaku adil. Jika manusia bisa bersikap adil terhadap hal yang bersifat duniawi dan tidak melupakan hal yang bersifat rohani, manusia tersebut akan mencapai kesempurnaan hidup yang tentram dan selamat.

\section{Sabar}

Sabar adalah perilaku yang tidak pernah marah kepada siapa saja. Manusia yang bersikap sabar memiliki sikap yang lembah manah. Dalam teks SPW dijelaskan bahwa orang yang sedang mendapatkan cobaan dari Allah harus bersikap sabar. Contoh dari perilaku sabar yang dijelaskan dalam teks $S P W$ diuraikan di bawah ini.

Pupuh 1 bait ke 12

...titahing Ywang Agung / samyå darbèni kapêsan / datan langgêng lêlakoning donyå iki / sor unggul kalah mênang//

Terjemahan:

...Umatnya Ywang Agung pasti memiliki kesialan yang tidak akan seterusnya sial didunia ini. Pastilah roda kehidupan ini berputar.

\section{Pupuh 1 bait ke 13}

yèn pinaring lêlakoning Widi/ lagyå asor sudrå påpå nisthål kalah lan sapêpadhanél kasurang sruka surung/ kasangsaran sinarang maring/ sagungé 
sanak kadang/ kadyå samyå ngriwuk/ ananging wis adatirå/ sok si åjå måhåmåhå laku sisip/ amung ngusap jåjål/

Terjemahan:

... Jika memperoleh cobaan dari Tuhan baru dibawah menjadi orang sudra, kalah dengan orang lain. Menjadi orang yang celaka dan sengsara hidupnya. Semua keluarga yang hanya memperhatikan. Janganlah mengungul-unggulkan dengan perilaku yang tidak baik, lebih baik dengan bersabar.

Dari keterangan di atas bisa diketahui bahwa manusia hars bersikap sabar dalam ketika mendapat cobaan dari Allah. Cobaan yang diberikan kepada umat bersifat tidak selamanya, akan tetapi cobaan tersebut bisa hilang jika manusia mau berusaha untuk bisa cepat terlepas dari cobaan tersebut. Cobaan dari Allah diibaratkan seperti roda yang berputar atau dalam bahasa Jawa disebut Cakra Manggilingan (Endraswara, 2003: 35). Manusia yang sedang mendapat cobaan harus bersikap sabar dan tetap harus berusaha untuk terlepas dari cobaan tersebut karena setelah terlepas dari cobaan manusia akan mendapatkan kemuliaan. Semua hal yang tertuju pada kesempurnaan hidup tentu akan menemui penghalan yang harus dijalani dengan tabah, teguh, dan tekun. Siapa saja yang menjalani cobaan dengan tabah, teguh, dan tekun serta bersikap baik dan jujur, sejatinya akan mencapai apa yang menjadi cita-citanya. Maka dari itu, manusia harus sabar dan tetap berusaha untuk kehidupannya.

\section{SIMPULAN}

Berdasarkan hasil penelitian dan pembahasan yang dijelaskan di atas, dapat disimpulkan bahwa naskah Serat Pustaka Wasiat mengandung berbagai ajaran yang utamanya adalah mengenai nilai-nilai etika hubungan manusia dengan diri pribadinya sendiri. Nilai-nilai etika tersebut yang ditemukan dalam naskah Serat Pustaka Wasiat ada tujuh jenis. Yang pertama adalah ahklak ngatiati, akhlak ngati-ati yang dimaksud adalah berhati-hati dalam berbicara sehingga tidak menyakiti hati lawan tuturnya. Kedua nrima, sikap nrima yang diajarkan adalah menerima apa saja yang diberikan Allah kepada umatnya, meskipun dalam bentuk cobaan maupun keberuntungan. Yang ketiga adalah sikap rumangsan. Sikap rumangsan yang dimaksud adalah ngrumangsani bahwa setiap orang memiliki aib sehingga tidak akan mengumbar aib orang lain. Keempat adalah waspada, waspada dalam bertindak atau berperilaku yang teresa-gesa. Waspada selanjutnya adalah waspada dalam sifat sombong dan sifat membuka aib orang lain. Kelima adalah mencegah hawa nafsu dengan cara laku prihatin. Laku prihatin tersebut bisa dilakukan dengan cara mencegah rasa kantuk dan laparnya. Keenam adalah adil dalam melakukan segala hal yang bersifat keduniawian dan yang bersifat kerohanian. Dan yang terakhir adalah sikap sabar. Sabar yang diajarkan adalah sabar dalam menjalani cobaan dan manusia harus berusaha kerluar dari cobaan tersebut.

\section{DAFTAR PUSTAKA}

Atmaja, Nata. 1894. Sêrat Puståkå Wasiat koleksi Museum Sånåbudåyå Yogyakarta kanthi kode PB C. 197.

Behrend, T.E. 1990. Katalog Induk Naskah-naskah Nusantara Museum Sonobudoyo Yogyakarta. Jilid I. Jakarta: Djambatan.

Ekowati, Venny Indria. 2017. Filologi Jawa: Panduan Lengkap Praktik Penelitian Filologi. Yogyakarta: UNY Press.

Endraswara, Suwardi. 2003. Budi Pekerti dalam Budaya Jawa. Yogyakarta: Hanindita Graha Widya.

Fathurahman, Oman. 2016. Filologi Indonesia Teori dan Metode. Jakarta: Prenadamedia Group. Hadiatmaja, Sarjana. 2011. Etika Jawa. Yogyakarta: Grafika Indah. 
Hudiarini, Sri. 2017. Penyertaan Etika Bagi Masyarakat Akademik di Kalangan Dunia Pendidikan Tinggi. Jurnal Moral Kemasyarakatan Vol. 2 No. 1, Juni 2017, hlm. 1-13.

Kaelan. 2005. Metode Penelitian Kualitatif Bidang Filsafat. Yogyakarta: Paradigma.

Magnis-Suseno, Franz. 1998. Etika Jawa. Sebuah Analisa Falsafi tentang Kebijaksanaan Hidup Jawa. Jakarta: PT Gramedia.

Musman, Asti. 2017. Pitutur Luhur Jawa Ajaran Hidup dalam Serat Jawa. Yogyakarta: Pustaka Jawi.

Pudjiastuti, Titik, dkk. 2018. Kamus Istilah Filologi. Jakarta: Badan Pengembangan dan Pembinaan Bahasa.

Santosa, Imam Budi. 2010. Nasihat Hidup Orang Jawa. Yogyakarta: Diva Press. 